\title{
WSPÓŁPRACA NIEZALEŻNYCH ORGANÓW ADMINISTRACJI PUBLICZNEJ
}

W artykule do rocznicowego, jubileuszowego tomu „Ruchu Prawniczego, Ekonomicznego i Socjologicznego" postanowiłem zwrócić uwagę na pewne zjawisko, które można określić mianem braku ducha współpracy między organami administracji, dla tego celu lepsze wydało mi się odejście od formuły klasycznego artykułu naukowego na rzecz formuły felietonu naukowego.

Jeden z wysoko postawionych członków kadry kierowniczej administracji publicznej, który kończył szkoły w Anglii, opowiedział mi, że mimo iż był bardzo dobrym uczniem, na świadectwach znajdywał uwagę, że powinien poprawić swego ducha pracy zespołowej - shall improve his team spirit. Mój rozmówca wskazywał, że brak ducha pracy zespołowej może być pewną naszą ułomnościa, $\mathrm{w}$ porównaniu z wieloma państwami zachodnimi. Widać to m.in. w przypadku działań organów i państwowych jednostek organizacyjnych wyposażonych w znaczny stopień niezależności od naczelnych organów administracji.

Szczególnie tzw. organy regulacyjne, zajmujące się nadzorowaniem poszczególnych obszarów życia gospodarczego, wyposażone są w znaczny stopień niezależności nie tylko od przedsiębiorców, lecz także innych organów administracji ${ }^{1}$. Ich niezależność przejawia się m.in. w niemożliwości wydawania im wskazówek co do sposobu działania, ograniczeniu czy wyeliminowaniu możliwości ingerencji w toczące się postępowania, ograniczeniu oddziaływania na obsadę personalną. To ostanie wyraża się często m.in. w obsadzaniu stanowiska prezesa organu regulacyjnego w drodze konkursu oraz ograniczeniu możliwości odwołania z zajmowanego stanowiska przed upływem kadencji.

Niewątpliwie niezależności tych organów sprzyja również fakt, że dwa z nich, a mianowicie Krajowa Rada Radiofonii i Telewizji oraz Komisja Nadzoru Finansowego, nie sa traktowane jako organy administracji rządowej. Potrzeba niezależności tych organów jest mocno akcentowana w przepisach unijnych wymagających ich powołania. Choć polskie przepisy określające ich sytuację prawną nie posługują się terminem niezależności, to jednak pozycja tych organów pozwala im często na działanie zupełnie niezależne od rządu i pozostałych organów administracji. Patrząc na działania tych organów, niejednokrotnie widzimy, że czują się one niezależne i tej niezależności pilnie

${ }^{1}$ Zob. K. Jaroszyński, M. Wierzbowski, Organy regulacyjne, w: System prawa administracyjnego, t. 6: Podmioty administracyjne, Warszawa 2011; M. Swora, Niezależne organy administracji, PWE 2012 i cytowana tam literatura. Problem jest szeroko omawiany w podręcznikach publicznego prawa gospodarczego. 
strzega. Przykładem moga być ich działania czasami wymierzone w działania rządowe, jak to miało miejsce choćby w ocenie działań podjętych wobec Otwartych Funduszy Emerytalnych. Był to zresztą przypadek szczególny, w którym słowa krytyki pojawiły się ze strony agend rządowych, od rządu zależnych, takich jak Prokuratoria Generalna czy Rządowe Centrum Legislacji. Była to szczególna sytuacja, wskazująca na pewną autonomizację jednostek organizacyjnych zajmujących się obsługą centralnych organów administracji.

Jak to szeroko w literaturze jest podnoszone, organy regulacyjne rozpowszechniły się, przejmując wzorzec amerykańskiej agencji, czyli tzw. niezależnych organów skupiających w sobie funkcję ustawodawczą wykonawcza i sądownicza. Funkcja ustawodawcza polega na wyposażeniu tych organów $\mathrm{w}$ bardzo szerokie kompetencje do wydawania przepisów powszechnie obowiązujących, takich, jakie uważają one za stosowne do sprawnego i poprawnego funkcjonowania regulowanej dziedziny gospodarki. Zasadniczo przepisy ustawowe prawie nie dają tu wskazówek co do zakresu regulacji. Oczywiście nie może ona naruszać obowiązującego prawa i jest poddana kontroli sądów. Funkcja wykonawcza polega na rozstrzyganiu spraw indywidualnych, a sądownicza - na możliwości nakładania kar, a także czasami rozstrzygania pewnych sporów.

Znawcy amerykańskiego systemu politycznego wiedza, że występują tam silne związki osobowe pomiędzy członkami tej samej partii politycznej, a także związane z kończeniem tych samych szkół, członkostwem w organizacjach i tak dalej. W dużym stopniu siła społeczeństwa amerykańskiego bierze się z poczucia przynależności grupowej i silnego poczucia lojalności wobec najwyższych organów władzy, w szczególności prezydenta. Stąd też do rzadkości należą sytuacje konfliktów w kręgu organów państwowych, w tym wspomnianych organów regulacyjnych. Podobne związki obserwujemy w innych krajach o długiej tradycji demokratycznej, często biorą się one z systemu wychowania w szkołach, w których kładzie się duży nacisk na współpracę w ramach grupy i ocenianie na podstawie wyniku całej grupy.

Wydaje mi się, że ciężko o podobne tendencje w społeczeństwie polskim. Transformacja gospodarcza i polityczna, która zakończyła okres socjalizmu, zaowocowała poczuciem wolności, niezależności i często niechęci do podporządkowywania się rozstrzygnięciom narzucanym przez państwo. Zaczęto silnie akcentować służebną rolę państwa wobec obywatela. Wykazanie się niezależnością niewątpliwie zdaje się podnosić wartość osoby zainteresowanej.

Transformacja w Polsce przyniosła też powołanie szeregu organów regulacyjnych, czy to dla pewnych dziedzin gospodarki (jak KRRiT, UKE, URE, ULC czy UTK) czy określonych aspektów działalności wszystkich podmiotów (np. UOKiK). Mają one za zadanie czuwanie nad określonym systemem wartości, przy czym nie muszą one brać pod uwagę całości ewentualnych skutków gospodarczych czy politycznych własnych rozstrzygnięć, ponieważ ich zadaniem jest czuwaniem nad jednym tylko aspektem działania podmiotów regulowanych.

Niewatpliwie takim zachowaniom sprzyja polityka Unii Europejskiej, dążąca do powiązania organów regulacyjnych w skali Unii i pewnemu oddzieleniu ich od innych organów danego państwa członkowskiego. Wyrazem tej ostatniej tendencji jest powierzanie rozstrzygania pewnych spraw orga- 
nom unijnym, choć z zasady rozstrzygają je organy krajowe, czy powstanie tzw. procedur kompozytowych, zgodnie z którymi część postępowania toczy się przed organami krajowymi, część zaś - przed unijnymi.

Powołane zostały też organy unijne dla pewnych obszarów spraw, a także stworzono organizacje, w których reprezentowani są regulatorzy z państw członkowskich; w ten sposób utworzono na mocy rozstrzygnięć organów unijnych takie organizacje, jak Organ Europejskich Regulatorów Łączności Elektronicznej (BEREC) ${ }^{2}$, Europejską Agencję Współpracy Regulatorów Energii ${ }^{3}$.

W zakresie organów nadzorujących rynek finansowy powstały organizacje w skali większej niż Unia Europejska, stworzono też na poziomie Unii Europejskiej odrębne organy nadzorujące ten rynek, mające w praktyce bieżacy kontakt z lokalnymi regulatorami. Sa to organy nadzorujace obszar bankowości (EBA), ubezpieczeń (EIOPA), papierów wartościowych (ESMA). Istnienie takich ciał i organów skutkuje pewnym ograniczeniem roli organów lokalnych i usamodzielnianiem się lokalnych regulatorów.

Wracając na grunt polski, wypada wskazać, że w systemie administracji rządowej, niezwykle istotną rolę odgrywa Rada Ministrów, posiadająca kompetencje wynikajace z Konstytucji, a także dysponująca np. uprawnieniami w zakresie kontroli całej administracji rządowej. Konstytucja przewiduje przecież, że Rada Ministrów prowadzi politykę wewnętrzną i zagraniczną Rzeczypospolitej (art. 146 ust. 1 Konstytucji RP). Rada Ministrów „kieruje administracja rządową" (art. 146 ust. 3 Konstytucji RP).

Zdecydowana większość organów administracji w Polsce ulokowanych na szczeblu centralnym to właśnie organy administracji rządowej. Trochę jakby poza tym obszarem leżą Krajowa Rada Radiofonii i Telewizji, której pozycję reguluje Konstytucja, państwowa Inspekcja Pracy i Komisja Nadzoru Finansowego, która Trybunał Konstytucyjny zakwalifikował jako organ nieleżący w obszarze administracji rządowej.

Przepisy dotyczące szeregu organów centralnych zaliczanych do grupy „regulatorów” niejednokrotnie traktuja je jako właściwie odrębne władze, a nie część jednolitego systemu administracji. Przykładem może tu być konieczność uzyskiwania odrębnych zezwoleń kilku organów na tę samą czynność. Skrajnym przykładem była przed paroma laty konieczność równoległego uzyskania zezwoleń kilku organów na nabycie znaczących pakietów akcji banków, będących w tzw. obrocie publicznym, kiedy w pewnych sytuacjach konieczne było równoczesne uzyskanie zgody Komisji Nadzoru Bankowego, Komisji Papierów Wartościowych i Giełd oraz Prezesa UOKIK. Choć każdy z tych organów jest częścią administracji państwowej i działa w imieniu Rzeczypospolitej, brak jednej zgody uniemożliwiał dokonanie transakcji. Mieliśmy również przepisy, zgodnie z którymi np. udostępnianie określonych informacji przez jeden organ administracji drugiemu miało się odbywać na zasadzie wzajemności, czyli or-

2 Body of European Regulators for Electronic Communications powołany przez rozporządzenie 1211/2009 Parlamentu Europejskiego i Rady z 25 listopada 2009 r. jako część pakietu Reformy Telekomunikacji (Telecom Reform package).

${ }^{3}$ European Agency for the Cooperation of Energy Regulators (ACER) powstała w 2010 r. na mocy rozporządzenia 713/2009 Parlamentu Europejskiego i Rady z 13 czerwca 2009 r. 
gany te były traktowane nie jako części jednego organizmu, lecz tak jakby były odrębnymi, samodzielnymi dzierżycielami władzy.

Rozstrzygnięcia organów regulacyjnych, choć nakierowane z reguły na jeden aspekt funkcjonowania podmiotów regulowanych, mają znaczenie szersze. Moga bowiem wpływać na inne gałęzie gospodarki. Przykładowo decyzje UOKiK dotyczace koncentracji będa miały znaczenie dla wielkości przedsiębiorców polskich i tym samym na ich zdolność konkurencyjna, zarówno w skali rynku krajowego, jak i międzynarodowego. Rekomendacje KNF dotyczące udzielania kredytów budowlanych mają istotny wpływ na funkcjonowanie sektora budowlanego, faktycznie bowiem maja wpływ na popyt na mieszkania.

Stąd też tradycja administracji europejskiej zakłada silną rolę koordynatora w postaci Rady Ministrów, czy innego organu naczelnego, który wykorzystując różne uprawnienia, ma możliwość wpływania i koordynowania działań różnych organów. Można też tworzyć czasami ciała zbiorowe, aby ich rozstrzygnięcia odzwierciedlały potrzeby różnych organów administracji. Przykładem może być tu skład KNF, w której zasiadają przedstawiciele kilku organów, obecnie Prezydenta Rzeczypospolitej Polskiej, Prezesa NBP, Ministra Finansów, Ministra Pracy i Polityki Społecznej. Wcześniej zasiadał w niej przedstawiciel Ministra Prywatyzacji, a potem Skarbu Państwa, co wiązało się z procesami prywatyzacji.

W demokracjach zachodnich brak wyraźnego koordynatora niezależnych organów regulacyjnych, w jakimś zakresie zastępuje go silna tradycja jednolitej administracji państwowej, ducha gry zespołowej, co powoduje, że choć nie ma takiego prawnego obowiązku, pewne działania organów niezależnych bywają koordynowane, a przed ich podjęciem często analizuje się ich wszelkie możliwe skutki.

Jakiś czas temu jeden z profesorów badał orzecznictwo niemieckich organów antymonopolowych wobec potentata, jakim są koleje niemieckie. Był niezmiernie zdziwiony, że przy tak dużym udziale w rynku przewozów nie występowały decyzje zawierajace sankcje wobec tego potentata. Można oczywiście zakładać perfekcyjność działania kolei niemieckich, ale można też przypuszczać, że niektóre przedsiębiorstwa, aktywne na gruncie międzynarodowym, mają pewne wsparcie państwa macierzystego, dzięki czemu ich siła konkurencyjna może być bardzo duża.

Trudno sobie wyobrazić, że przepisy ograniczyłyby samodzielność organów uważanych za niezależne organy regulacyjne. Byłoby to zresztą sprzeczne z przepisami unijnymi. Można jednak sobie wyobrazić stosowanie pewnych niewładczych form współpracy, czy pewnej koordynacji posunięć, co - skoro nie jest zakazane - dawałoby korzyści w postaci wszechstronnego uwzględniania skutków rozstrzygnięć organów regulacyjnych przed ich podjęciem. Moga też rozwijać się różne formy bilateralnej współpracy między organami, co zresztą czasami ma miejsce z korzyścią dla obu współpracujących organów, a także podmiotów regulowanych. 


\section{COOPERATION OF INDEPENDENT ADMINISTRATIVE AUTHORITIES}

\section{Sum mary}

There is not much cooperation among administrative bodies in Poland. Following the pattern established by American independent regulatory agencies, Poland created a number of regulatory organs and equipped them with a large amount of independence in relation to other administrative bodies. They are no longer obliged to act according to instructions, there is also a special competition-like system of appointing and removal of head officers of such agencies.

From the activity of independent regulatory agencies it may be deduced that they act as fully independent entities. This assumption may by drawn from examples such as the reaction towards some actions taken by the Council of Ministers as in the case of the restrictions imposed on the activity of pension funds, introduced by the central government and criticised by some other administrative bodies, even those closely linked to the Council of Ministers (the Government Centre for Legislation). Independence of several regulatory organs is also required by the EU.

Frequently, decisions made by regulatory organs have a strong impact on the entire economy of the country. For example, the recommendation of the Commission of Financial Supervision concerning granting loans by banks for the purchase of new apartments - a project aimed at reducing the risk in the banking sector, turned out to have had a substantial impact on the entire construction sector of the national economy, and reduced the demand for new apartments altogether.

Independence of the regulator does not mean that the rest of public administration, and the Council of Ministers being a coordinator of the activities of the entire public administration in particular, should be disregarded. Especially, great impact actions should be coordinated. Different forms of bilateral cooperation should also be developed. 
Copyright of Journal of Law, Economics and Sociology is the property of Faculty of Law and Administration of Adam Mickiewicz University in Poznan and its content may not be copied or emailed to multiple sites or posted to a listserv without the copyright holder's express written permission. However, users may print, download, or email articles for individual use.

Właścicielem praw autorskich do „Ruchu Prawniczego, Ekonomicznego i Socjologicznego” jest Wydział Prawa i Administracji Uniwersytetu im. Adama Mickiewicza w Poznaniu. Zawartość czasopisma nie może być kopiowana, przesyłana do innych stron internetowych bądź zamieszczana na blogach bez pisemnej zgody wydawcy. Niemniej artykuły można drukować, kopiować lub przesyłać w formie elektronicznej na własny użytek. 